Article

\title{
Personalization of Products in the Industry 4.0 Concept and Its Impact on Achieving a Higher Level of Sustainable Consumption
}

\author{
Sebastian Saniuk ${ }^{1, *(D)}$, Sandra Grabowska ${ }^{2}$ (D) and Bożena Gajdzik ${ }^{3}$ (D) \\ 1 Department of Engineering Management and Logistics Systems, University of Zielona Gora, \\ 65-246 Zielona Gora, Poland \\ 2 Department of Production Engineering, Silesian University of Technology, 40-019 Katowice, Poland; \\ sandra.grabowska@polsl.pl \\ 3 Department of Industrial Informatics, Silesian University of Technology, 40-019 Katowice, Poland; \\ bozena.gajdzik@polsl.pl \\ * Correspondence: s.saniuk@wez.uz.zgora.pl; Tel.: +48-506-288-047
}

Received: 14 September 2020; Accepted: 10 November 2020; Published: 12 November 2020

\begin{abstract}
Sustainability is among the most important directions in global development. The challenge today is to reconcile the fastest possible economic growth and the pursuit of prosperity with concern for the environment. One of the important problems of modern economies and societies is to reduce overall consumption and implement new patterns of sustainable consumption and production. The main aim of this article was to analyze consumer preferences in terms of purchasing personalized production offered by implementing the concept of Industry 4.0 and ensuring sustainable consumption and production (SCP). Based on the analysis of the literature and the results of our own research, an attempt was made to estimate the impact of personalized production offered by the Industry 4.0 concept on SCP and thus the sustainable development of the economy. This article presents the results of a survey conducted on a selected group of consumers, focusing on learning about expectations, consumer preferences for personalized products and conscious consumption, and the results of a survey conducted using the Servqual method, determining the level of customer satisfaction with the purchase of personalized products. The most important achievement was to demonstrate a high level of consumer satisfaction with buying personalized products and the positive impact of personalized production on sustainable consumption. At the same time, the importance of developing the Industry 4.0 concept for supporting sustainable consumption-oriented consumer behavior is emphasized.
\end{abstract}

Keywords: Industry 4.0; sustainability; sustainable consumption and production (SCP); personalized products; customization

\section{Introduction}

The great challenge of today's developing economies is to maintain a balance between rapid economic growth and society's desire for prosperity and environmental protection, which requires the continuous improvement of products, optimization of production technology, so as to produce products with the best possible performance, with the least possible use of raw materials and environmental impact, while maintaining economic viability. Sustainability is described in many international documents. To achieve sustainability, at a time of rapid climate change and increasing demand for energy and resources, national governments are implementing a number of strategies and initiatives aimed at sustainable consumption and production (SPC). The level of modern consumption contributes to serious environmental problems reflected in climate change (global warming), the degradation of 
the world's ecosystem, resource depletion, the impoverishment of biodiversity or water, air and soil pollution, but also causes social stratification [1].

One of the key problems of the modern world is the need for the limitation of consumerism, which is particularly responsible for the excessive consumption of natural resources. The opportunities offered by the Industry 4.0 concept should be taking advantage of new marketing strategies which should be formulated in such a way as to enable balance and minimize the effects of over-consumption [2]. This also means that the introduction of new patterns of quality of life and ideas of well-being, especially in developed countries. Hence, there is growing talk of so-called sustainable consumption patterns, which is a form of consumption directly linked to the concept of sustainable development, oriented towards long-term socio-economic goals, especially in terms of positive environmental impact [3]. Sustainability and sustainable consumption and production (SCP) are essential to ending poverty, protecting the planet and improving the quality of life and prospects for all people. Therefore, all the UN member states have adopted 17 targets in 2015 as part of the 2030 Sustainable Development Agenda. The 12th Agenda 2030 aims to ensure sustainable consumption and production patterns. In paragraph 28 of Agenda 2030, member states have committed themselves to "making fundamental changes in the way our societies produce and consume goods and services [4,5]. Governments, international organizations, the business sector and other non-state stakeholders and consumers must contribute to changing unsustainable consumption and production patterns, including by mobilizing, from all sources, financial and technical assistance to strengthen developing countries' scientific, technological and innovative capacities to move towards more sustainable consumption and production patterns" [6].

Based on the analysis of the literature, a clear research gap has been identified in the area of the impact of personalized production on customer satisfaction and sustainable consumption, especially in the era of the development of the Industry 4.0 concept. This means that the need for research in the area of personalized production of Industry 4.0, the impact of personalized products on the perceived customer satisfaction with the purchase and use of such goods, consumer involvement in the creation (design) and manufacture of the product. Currently, the authors of many scientific publications emphasize the lack of recognition of the impact of personalized production on achieving higher levels of sustainable consumption. This is related to the better adaptation of the product to the customer's expectations, greater satisfaction with the purchased products and their longer life (longer product life cycle).

The article adopts the following research hypothesis: "a high level of product personalization affects a high level of customer satisfaction with the purchase and finally ensuring sustainable consumption". The main aim of the article is to analyze consumer preferences for purchasing personalized production offered by implementing the Industry 4.0 concept and achieving sustainable consumption and production.

The most important achievements in the article are:

- To demonstrate a high level of consumer satisfaction with the purchase of personalized products;

- To demonstrate the positive impact of personalized production on sustainable consumption;

- To examine consumer expectations and preferences for personalized production in the context of the development of the Industry 4.0 concept;

- To demonstrate the level of involvement of customers in the process of creating personalized products;

- To demonstrate the importance of developing the Industry 4.0 concept for supporting sustainable consumption-oriented consumer behavior.

\section{Background and State of Research}

\subsection{Sustainable Consumption and Production (SCP)}

One of the main assumptions of the SCP concept is the consumption of goods produced with respect for environmental aspects related to minimizing the use of raw materials, reducing waste and 
pollution while improving quality of life [4]. This means that the modern production of goods and services and customer orientation should be combined with the concept of sustainability. The SCP concept is based on three principles: economic rationality (economic optimization in the selection of goods), ecological rationality (selection of goods that least harm the environment) and social rationality (selection of goods that solve social problems or do not contribute to their deepening). The SCP concept tries to combine, on the one hand, the need to satisfy needs, improve the quality of life and on the other hand, improve resource efficiency, increase the use of renewable energy sources, and minimize waste. The integration of these elements is the main goal of modern economies, which want to provide the same or better services to meet the basic requirements of life and aspirations to improve the quality of life while constantly reducing environmental damage and risks to human health. The key issue is, therefore, the extent to which the necessary environmental improvement can be achieved through the substitution of more efficient and less polluting goods and services (patterns of consumption), rather than through reductions in the volumes of goods and services consumed (levels of consumption). This means the need to change consumption patterns and reduce consumption levels. In conclusion, sustainable consumption is an interpretation of the concept of sustainable development related to consumption [3]. In the article, consumption is understood as the use of possessed goods in order to directly satisfy one's own needs. It results from the usefulness of the product or service being consumed, which can also be subjective and complementary to the consumer. Currently, the term of consumption may be extended to sharing issues according to the idea of a sharing economy (temporary use of a product). Packaging, on the other hand, is an element of personalization, e.g., a gift with a dedication or a can of Coca-Cola with the name of the consumer, etc., promoting sustainable consumption requires the involvement of both professionals and public authorities and individuals.

Legislative changes are also necessary to introduce restrictions on the freedom of production and waste management. In addition to governmental and public documents, the subject of sustainable consumption is the subject of scientific research. The authors of scientific publications, describing sustainability in consumption and production, refer to the essence of sustainable development. In this part of the publication, which is an introduction to the presentation of the results of direct research in the area of the impact of personalization on sustainable consumption, general content about sustainable consumption and personalization is given, especially in the era of the implementation of the Industry 4.0 concept.

\subsection{Personalization in the Era of Industry 4.0}

New technological solutions promoted within Industry 4.0 should contribute to increasing the production and environmental performance of products throughout their life cycle. It is also related to the increased demand for smart products and smart production technologies. In a sustainable market, consumers should make informed choices when buying "environmentally friendly" products, i.e., those that are recycled, serviced, renewable, shared, etc.

Nowadays, customers expect products tailored to their personal preferences, tastes, needs and lifestyle. They want to influence the configuration of manufactured products and receive good products [7]. Therefore, there is a need for a completely new, more modern and innovative approach to production and business management, which will significantly increase flexibility, efficiency and customer focus. The paradigm of mass production has been changed in favor of customized production, tailored to the needs of individual customers (e.g., personalized products) [8-10]. Examples of personalized products are shoes offered by e.g., Adidas company, created according to the customer's own idea (they determine the color of the shoes, insole and laces), the similar offer has Nike, Timberland and Converse, or Burberry. Many interesting examples are offered by companies from the automotive industry, e.g., a very detailed specification of Maybach car equipment, etc.

The notion of personalization is not unequivocally defined, although the common features of this approach indicated in the literature are customer preferences, customer participation in the product design process, customization and information flow between customer and manufacturer [11]. 
Personalization allows the customer to feel the exclusive or preferred recipient of the product or service [12]. Personalization is a firm's decision on the marketing mix suitable for the individual that is based on previously collected customer data [13]. Personalization is a limiting case of mass customization. Mass customization aims at a market segment of few, whereas mass personalization aims at a market segment of one [14]. Mass customization aims at the customization and personalization of products and services for individual customers at a mass-production price [15]. Customizing some feature of a product or service means that the consumer of the product enjoys more convenience or some other benefit. This is initiated by the consumer or the company [16]. The production and sale of personalized products, services, content, and communication to the needs of a single consumer or groups of consumers is carried out by recognizing the needs of individual consumers based on their personal data and information about their purchasing preferences [16-18].

The need to offer highly personalized products on the market forces companies to change the current "modus operandi" oriented towards a higher level of interaction between the company and consumer. Consumers are involved in the creation process and even the final assembly of the product. The consumer of personalized products is treated as the customer of the manufacturing enterprise, not as an anonymous consumer of products. As a result, the interaction between the customer and manufacturer is stronger. The companies strive to reduce production costs, which is achieved, among others, through World Class Manufacturing (WCM) standards, custom production, rational resource management, the development of networked forms of cooperation, the automation and robotization of production, transfer of certain processes to customers, e.g., co-design, assembly, product improvement, etc. [19]. Significant improvements in production efficiency are achieved by saving material, energy, production and labor resources [20]. The resources are at the entry point of production and have the largest share in production costs. The direction of change in the pursuit of resource-saving is in line with the principles of sustainable development. Products made according to the "zero waste" principle are sustainable products.

Personalized products, services and marketing communications can support customer retention and loyalty by meeting their hidden needs [21]. The personalization scheme can be repeated many times with each subsequent customer, resulting in mass personalization [22]. Mass personalization requires the product to be adaptable and configurable, because not only the final product, but also the basic design packaging should be able to differentiate the product to meet individual preferences [23].

The Industry 4.0 concept, which supports mass personalization, allows to achieve sustainable consumption in a very broad context with consideration of (1) horizontal integration across the entire value creation network, (2) end-to-end engineering across the entire product life cycle, as well as (3) vertical integration and networked manufacturing systems and strong capital ties [24-27]. This broad view of the Industry 4.0 paradigm allows placing the importance of personalized products in sustainable production and consumption in companies, the supply chain, economies and societies. The problems caused by shrinking resources, on the one hand, and increasing waste, on the other hand, can be solved by personalized production, which is supposed to lead to sustainable consumption. Mass personalization assumes the active participation of customers in the entire production process. The adaptation of products and services by the producer for the consumer using information inferred from the consumer's behavior or transactions. Personalization is automated by the marketer on behalf of the customer as opposed to customization that a customer requests on their own behalf [21].

In addition to adapting the product to the customer's individual preferences, personalization aims to reduce the cost of processing their order [12] and to obtain a higher value of the product (e.g., by 3D printing) [23]. Mass personalization means active interaction with customers, and the level of product creation is transferred from a physical product to acquiring knowledge about customer needs and building consumer satisfaction. Nowadays, the role of the consumer is changing-from purchase from the available range, through the choice of product configuration, to active participation in the design phase [28]. However, each successive model of meeting customer needs requires more flexible and technologically advanced production systems $[19,29]$. 
The development towards Industry 4.0 presently has substantial influence on sustainable consumption. The industrial value creation is currently shaped by the development towards the Industry 4.0. It is based on the establishment of smart factories, smart products and smart services embedded in an Internet of Things and of services also called industrial internet [30]. Each of the industrial revolutions to date has brought about a breakthrough in manufacturing processes, primarily enabling the increased efficient and mass production of goods and services. On the other hand, there have been changes in the environmental impact, both in terms of quality and quantity. Using the technology of Industry 4.0 creates an opportunity for the better adjustment of supply to demand, greater consumer involvement in the production process, reducing production costs, strengthening competitiveness and limiting the scale of environmental degradation and resource consumption.

The ongoing technological changes are accompanied by a gradual evolution of consumption patterns, resulting in the coexistence of various production paradigms, adapted by companies according to their capabilities and demand. Manufacturers in Industry 4.0 are striving to meet the latent needs of consumers and the growing involvement of customers at every stage of the product life cycle [31]. Manufacturers use the latest technologies to track product life cycle, such as RFID (Radio-frequency identification) and codes, such as QR (Quick Response). The product life cycle enables intelligent manufacturing research that is used for product development [32]. The customer's participation in these studies is therefore justified by the analysis of product use. Therefore, the consumer is an equivalent business partner and their decision-making process is balanced [33-35]. The consumer becomes aware of sustainability, participates in product design, follows the life cycle of the product, orders the product according to their needs, uses the product according to its intended use, etc., and consumes it sustainably.

\section{Materials and Methods}

The general model of research as a theoretical and conceptual framework of research adopted in the article is presented in Figure 1. Based on a critical analysis of the literature, a research gap was identified and a research hypothesis was adopted. The conceptual framework presents the predicted relationship between personalized products, customer satisfaction and sustainable consumption and production, which will be proven by using survey methods CAWI (Computer-Assisted Web Interview) and Servqual.

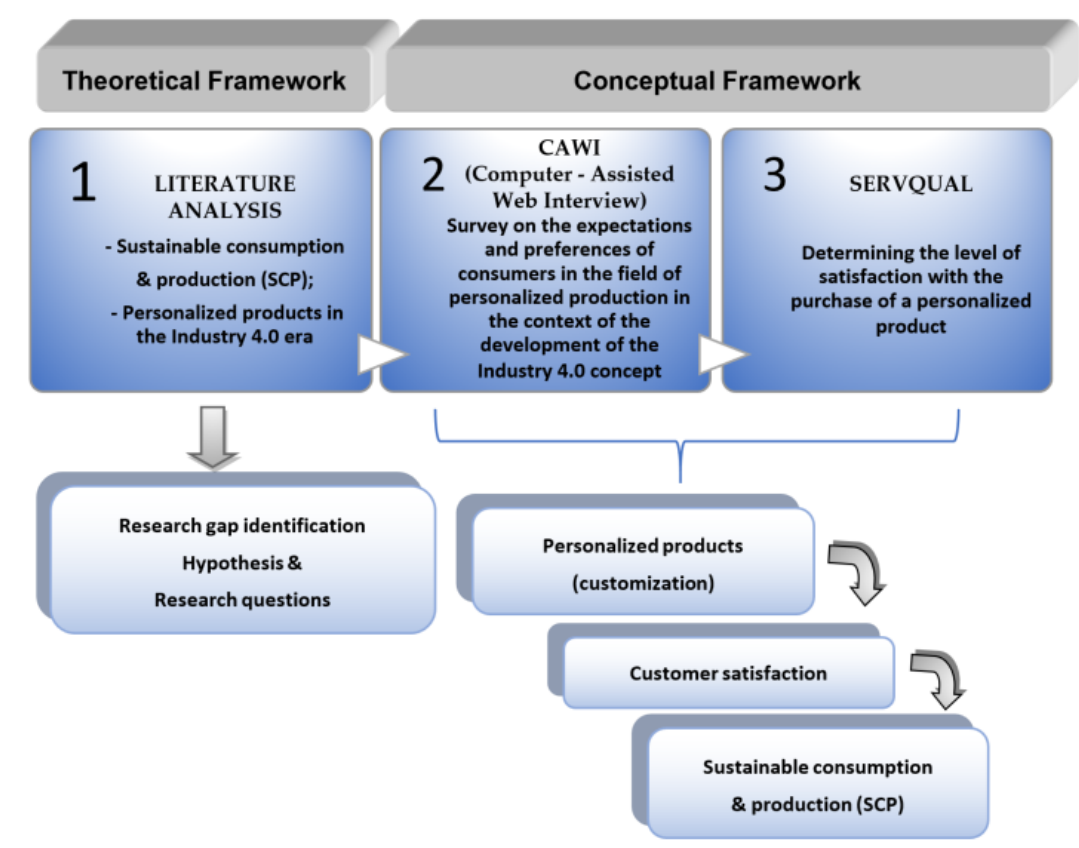

Figure 1. Theoretical and conceptual framework of research. Source: own study. 
In proving the adopted research hypothesis and the achievement of the objective of the article, the results of a survey on "Industry 4.0-consumer expectations" conducted at the turn of 2019 and 2020 were used, among others. The research consisted of two stages. The first stage of the study was to diagnose the general attitude of consumers to the phenomenon of the personalization of products, while the second stage of the study consisted in assessing consumer satisfaction with the purchase of a personalized product. Stage I of the study was conducted using the computer-assisted web interview method (CAWI) which is a standardized method of computer intelligence conducted using the Internet. The research tool was a questionnaire consisting of 20 questions (closed, complex, filtering, conditional and tabular). The questionnaire focused on questions about personalization-customers' expectations and preferences. The questionnaire was validated, through a pilot study among 10 experts with knowledge about production and Industry 4.0 personalization. The questionnaire was improved based on the comments of experts. The respondents were consumers residing in Poland, the country which is a representative of an emerging economy. The choice of an emerging market for the research is purposeful because of a quick response to changes and consumer behavior compared to the established consumer behavior of developed European economies.

Assuming a confidence level of 0.99 and a $10 \%$ error, the minimum size of the general population should be 166 respondents. Therefore, the information contained in the received questionnaires can be treated as representative-710 opinions were obtained. Selected information about the respondents participating in the CAWI survey is presented in Table 1.

Table 1. Information on respondents participating in the CAWI study.

\begin{tabular}{|c|c|c|c|c|c|c|c|c|c|c|}
\hline \multirow[b]{2}{*}{ Age $\backslash$} & \multicolumn{2}{|c|}{ Sex } & \multicolumn{4}{|c|}{ Place of Residence } & \multicolumn{4}{|c|}{ Material Situation } \\
\hline & $\mathbf{W}$ & $\mathbf{M}$ & Village & Small Town & Medium City & Big City & Very Good & Good & Not Bad & Bad \\
\hline Below 18 & 45 & 34 & 10 & 9 & 42 & 18 & 20 & 38 & 18 & 3 \\
\hline $19-25$ & 154 & 118 & 62 & 63 & 72 & 75 & 23 & 190 & 55 & 4 \\
\hline $26-35$ & 45 & 52 & 20 & 24 & 32 & 21 & 15 & 62 & 17 & 3 \\
\hline $36-45$ & 62 & 45 & 28 & 24 & 30 & 25 & 33 & 60 & 12 & 2 \\
\hline $46-55$ & 26 & 28 & 15 & 12 & 14 & 13 & 6 & 35 & 11 & 2 \\
\hline $56-67$ & 33 & 28 & 15 & 12 & 25 & 9 & 15 & 25 & 21 & 0 \\
\hline Over 67 & 22 & 18 & 9 & 13 & 8 & 10 & 9 & 17 & 12 & 2 \\
\hline /sum & 387 & 323 & 159 & 157 & 223 & 171 & 121 & 427 & 146 & 16 \\
\hline
\end{tabular}

The main aim of this survey was to determine the real needs of customers related to the purchase of personalized products offered by different industries (manufacturers). The survey sought answers to the following questions:

1. What are consumers' expectations and preferences regarding personalized production in the context of the Industry 4.0 concept development?

2. How do customers perceive their involvement in the process of creating personalized products?

3. Does purchasing personalized products contribute to increasing the level of sustainable consumption?

The second stage of the research was conducted among the respondents who confirmed that they buy personalized products in the first stage. The survey was attended by 368 respondents-it can thus be considered a representative sample. The modified Servqual method was used to determine the level of satisfaction with purchasing a personalized product. The assessment took into account the quality of customer service, as assumed by the Servqual method. The method was modified to reduce the 22 statements/questions to 18 statements/questions dedicated to the purchase of personalized products. The main aim of this stage of the research was to seek answers to the following questions:

1. What elements of the whole process of designing, purchasing and finalizing the order are most important for the respondents? 
2. Does the level of satisfaction with the service of design, purchase and finalization of this transaction affect the final assessment of the product itself, satisfaction with it, etc.?

In line with the Servqual method, five main factors were identified that influenced the customer's satisfaction of buying personalized products. These are: reliability, assurance, tangibles, empathy, responsiveness. The evaluation questionnaire contained two spheres: expectations and perceptions, each of which consisted of 18 statements. The questionnaire was divided into three parts:

- The first one concerned the customer's expectations of purchasing personalized products (this assessment was made by 10 experts with knowledge of production personalization and Industry 4.0);

- The second part was related to the evaluation of the purchase and use of a personalized product (this part was attended by 368 respondents);

- In order to measure the statements in both parts one and two, a seven-grade Likert scale was used, grade 1 meant that the experts/respondents strongly disagreed and 7 indicated that they strongly agreed with the specific statement;

- The third part was related to the determination of statements that were used to recognize the importance of particular dimensions for customers.

The respondents assessed the significance of particular groups of dimensions (they received 100 points, which they divided into specific dimensions of the level of satisfaction of purchasing personalized products).

The Servqual test procedure included five steps:

Step I-the analysis of the difference between the expectations and observations expressed in the points and described by formula (1):

$$
\mathrm{SS}=\mathrm{E}-\mathrm{P}
$$

where:

SS- the level of satisfaction;

E-individual expectations before buying towards the purchase of a personalized product (assessment before making a purchase);

$\mathrm{P}$-an individual perception of purchasing a personalized product (assessment of the purchase made).

Step II-the calculation of the average for the difference of points for each of the analyzed ranges.

Step III-the obtained results are summed up and then divided by the number of analyzed ranges.

Step IV-the calculation of the weighted measure of consumer satisfaction level. The data received in Step 2 are multiplied by the weights which determine the specific dimension from the third part of the questionnaire. The result obtained is the product of the arithmetic measures in relation to each satisfaction level dimension, and also presents the weighted average Servqual.

Step V-the obtained average was summed up and then divided by the number of analysis dimensions.

\section{Results and Discussion}

\subsection{Stage I-Results of Research}

The results of the research conducted in Stage I show that $52 \%$ of respondents confirm the purchase of personalized products, in which one can individually determine the characteristics of the product according to your taste/needs. The rest of the respondents (48\%) denied it. A large part of this group of respondents was most likely unaware that they very frequently bought personalized products, e.g., when ordering pizza. The division into two groups of consumers is presented in Figure 2. 

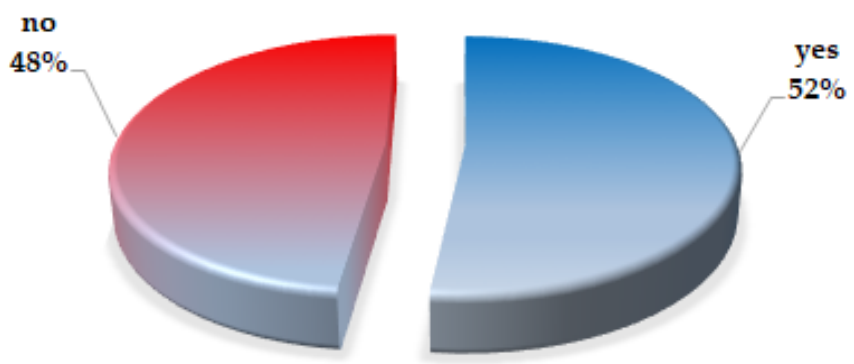

Figure 2. Declaration of respondents concerning the purchase of personalized products. Source: own study.

Personalized products are most often purchased by consumers aged 19-25 (38.04\%), 26-35 $(14.95 \%), 36-45(15.76 \%)$, rarely by consumers aged $56-67(7.61 \%)$, and very rarely by consumers over $67(1.36 \%)$. Based on these results, it can be seen that the most active group of consumers purchasing personalized products are young people aged $19-45$ years.

It seems that in today's market reality, everything that consumers need is already available and companies should focus on fighting their competitors, e.g., by lowering costs and prices, conducting more effective promotional activities or using other tools, from a very rich spectrum of marketing management instruments. However, today's customer is very demanding, wants to be unique, wants to reap the physical and emotional benefits of consuming, possessing and using products that are perfectly suited to their needs. It is a client who values uniqueness above all else. Nowadays, the customer wants to have an exceptional home, an exclusive car, a unique watch or branded clothes [36].

The products most often personalized by respondents are the purchase of RTV (consumer electronics) equipment (42\%), catering/food (39\%), personalized accessories (logo on case, pens, etc.) $(33 \%)$. Consumers also like to personalize clothes and shoes $(26 \%)$, jewelry $(25 \%)$ and toys for kids (24\%). They use beauty/cosmetics (17\%), cars purchase (15\%), household appliances (15\%) and software (computer, telephone) (13\%) less frequently. The purchase of personalized products by their groups (categories) is shown in Figure 3.

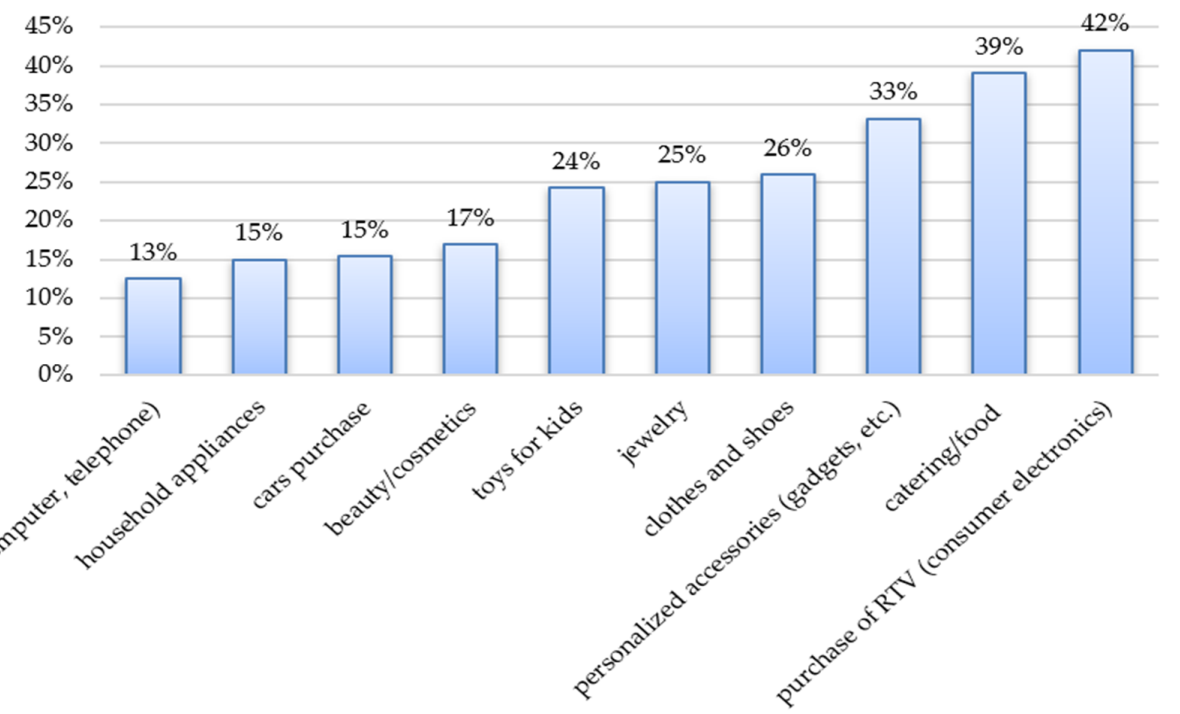

Figure 3. Purchases of personalized products by relevant product groups. Source: own study.

The knowledge of separate groups of personalized products, which are already being willingly purchased by consumers, provides excellent information for companies introducing the Industry 4.0 concept and introducing a high level of production customization. This means investment certainty in this area and the orientation of marketing activities towards the personalization of these products. 
When asked about the most expected variant of customization in the case of particular product groups in the era of Industry 4.0, the respondents most often indicated ( $30 \%$ and more) that:

- Pure customization is expected when buying catering and food $(38 \%)$, jewelry $(42 \%)$, furniture/home and garden equipment (37\%), clothes and shoes (44\%);

- Tailored customization respondents most often choose to buy: furniture/home and garden equipment $(37 \%)$, catering and food $(31 \%)$, clothes and shoes $(31 \%)$, cars $(32 \%)$;

- Customized standardization is chosen when buying: RTV equipment (36\%), toys for kids $(32 \%)$, beauty/cosmetics (31\%), cars (30\%), household appliances (30\%);

- $\quad$ Pure standardization dominates when buying: products of general use (35\%).

The results are shown in Figure 4.

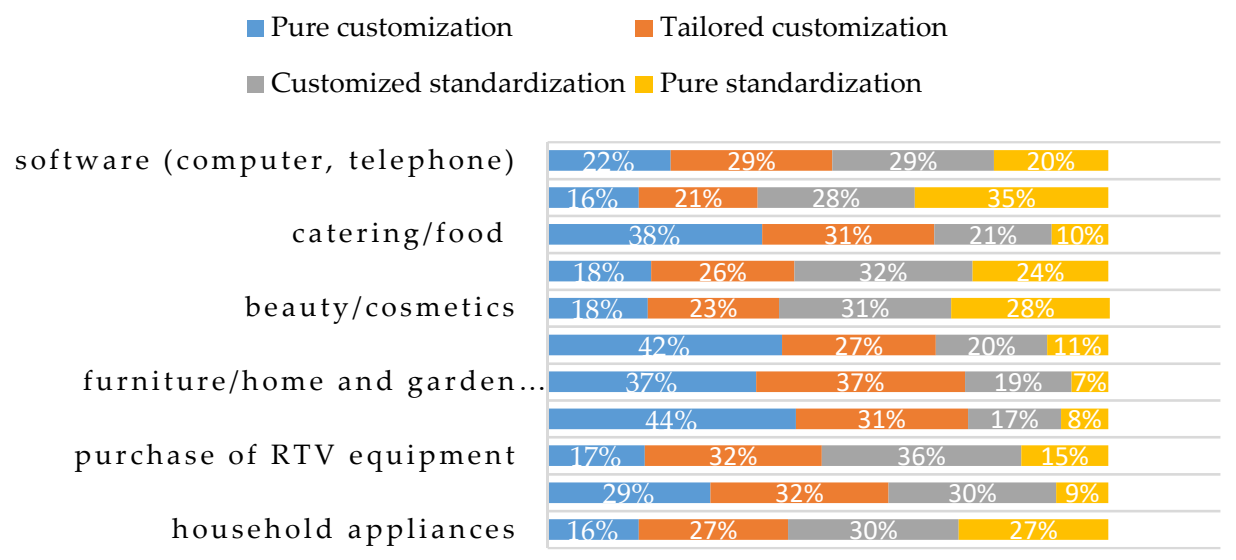

Figure 4. Expected customization variants for individual product groups. Source: own study.

The results presented in Figure 4 are important information for enterprises concerning the level of customization that is expected by the modern consumer for particular groups of products in order to invest in IT tools in the area of consumer involvement in the process of creating a personalized product.

Figure 5 shows the acceptable waiting time for the ordered personalized product. For products of general use, most customers are willing to wait up to a week (44\%), catering services-up to a few hours $(67 \%)$, toys-up to a week $(42 \%)$, beauty/cosmetics-up to a week $(43 \%)$, jewelry-up to a week (35\%), furniture equipment-up to a month (35\%), clothes and shoes-up to a week $(41 \%)$, electronics - up to a month (31\%), motorization/passenger cars-up to 6 months (37\%).

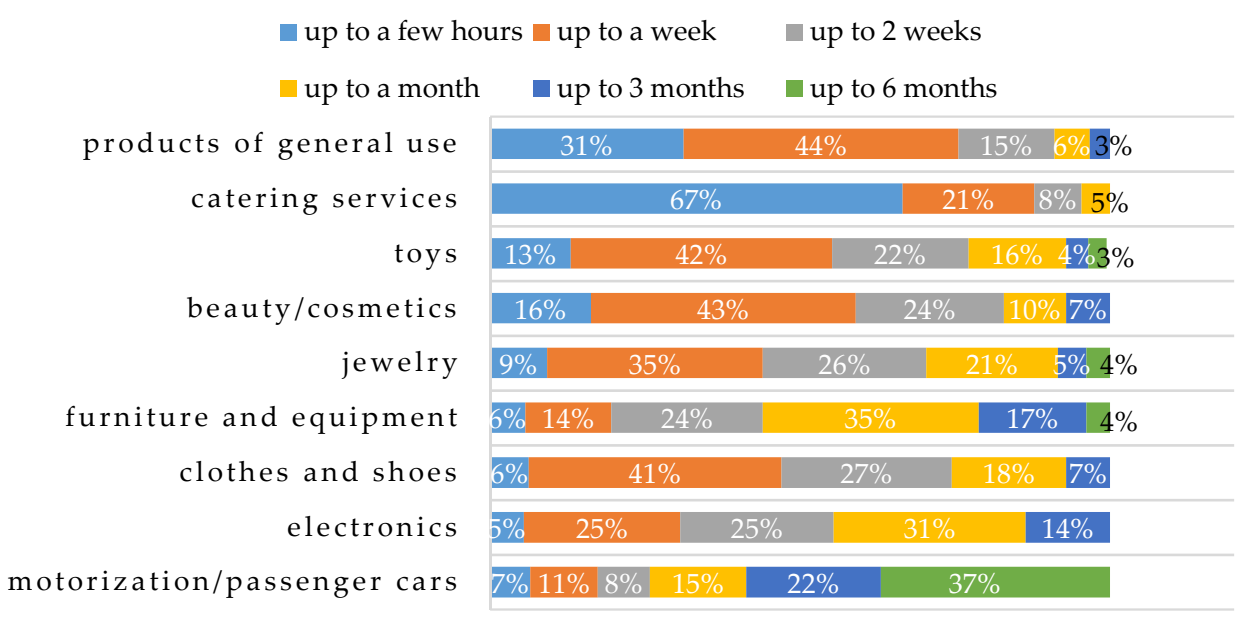

Figure 5. Acceptable waiting time for a personalized product. Source: own study. 
The results presented mean that there is a great need to personalize products, especially for more complex products. The time of waiting for a personalized product and participation in the selection of options or product design proves high consumer maturity. A mature consumer wants to purchase products tailored to their needs and use them for a long time if they meet their expectations. This is a prerequisite for achieving a higher level of sustainable consumption.

As Ciechomski [37] points out, the phenomenon of personalization lies in the emotional involvement of the consumer in creating the desired product. The above sentence is confirmed by the assessment of the prerequisites for the purchase of a personalized product. Respondents decide to buy personalized products (Figure 6) because they are unique products (52\%), guarantees that they feel unique (46\%), are great for a gift that reflects the recipient's expectations $(42 \%)$, guarantee higher product quality (39\%), influence on the product (34\%), guarantee greater comfort of using $(33 \%)$, better reflects their personality $(29 \%)$, guaranteed increase in value in the future $(25 \%)$, the best for collecting (12\%).

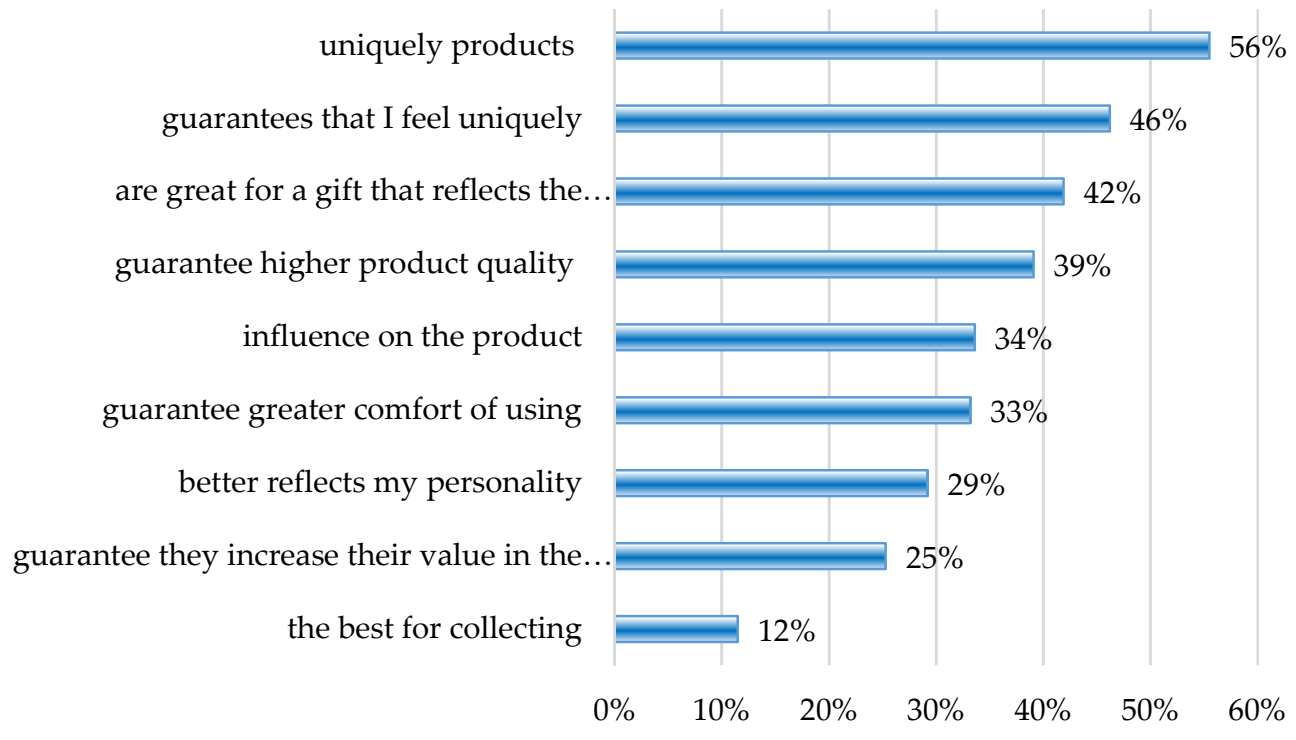

Figure 6. Main reasons for purchasing personalized products. Source: own study.

Most of the respondents (52\%) believe that personalized products are unique, whilst only $4 \%$ of the respondents absolutely disagree (Figure 7).

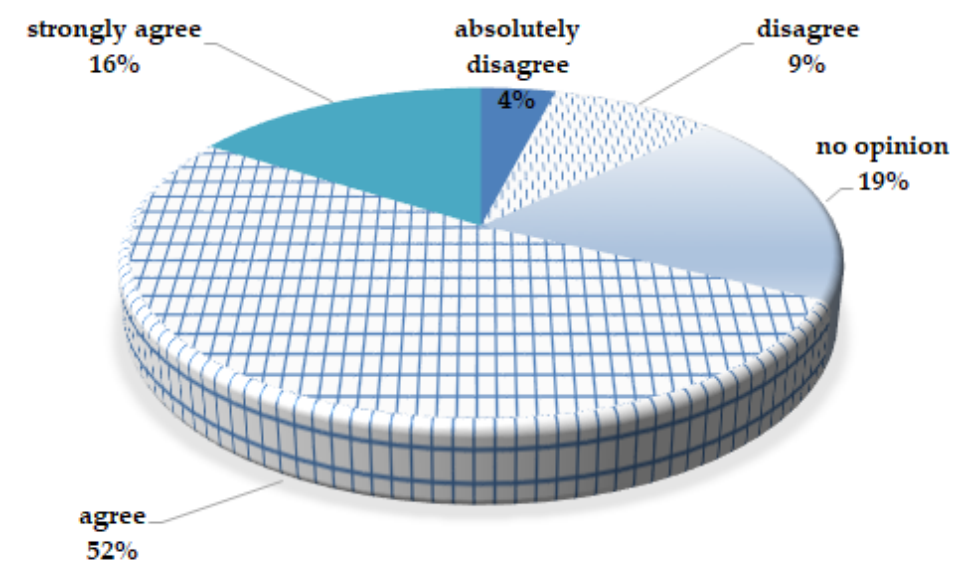

Figure 7. Subjective evaluation of the uniqueness of personalized products. Source: own study.

The level of emotional involvement in creating personalized products was assessed by $38 \%$ of respondents as very high, $28 \%$ as high, $22 \%$ as medium level, $7 \%$ as low level and only $5 \%$ of 
respondents chose a very low level answer (Figure 8). The results of the survey of respondents presented in Figure 8 are an additional argument for the development of personalized production and greater consumer involvement in the process of creating new products through, for example, specialized IT systems connecting the consumer with the manufacturer. This means that in the future there will be more interest in custom production than in buying standard products.

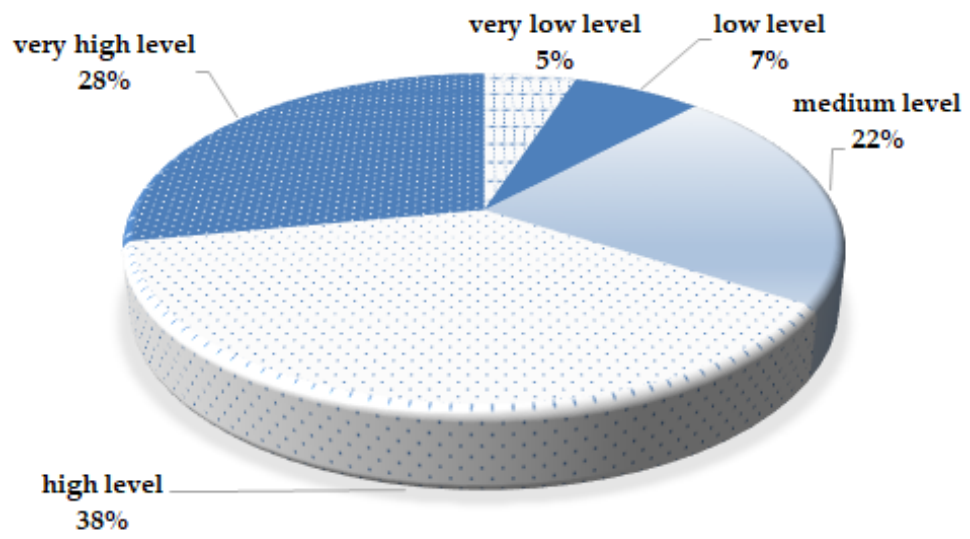

Figure 8. Emotional involvement of respondents in creating personalized products. Source: own study.

A vast majority of the respondents (definitely yes-24\%; and probably yes- $45 \%$ ) pay attention to whether they buy a product from a socially responsible entrepreneur (applying the principles of sustainable development and social responsibility). For only $3 \%$ of respondents, this aspect does not matter (Figure 9). The obtained results testify to a high level of consumer awareness and refer to the currently promoted behaviors of conscious purchasing of environmentally safe products manufactured by manufacturers with a high level of CSR (corporate social responsibility).

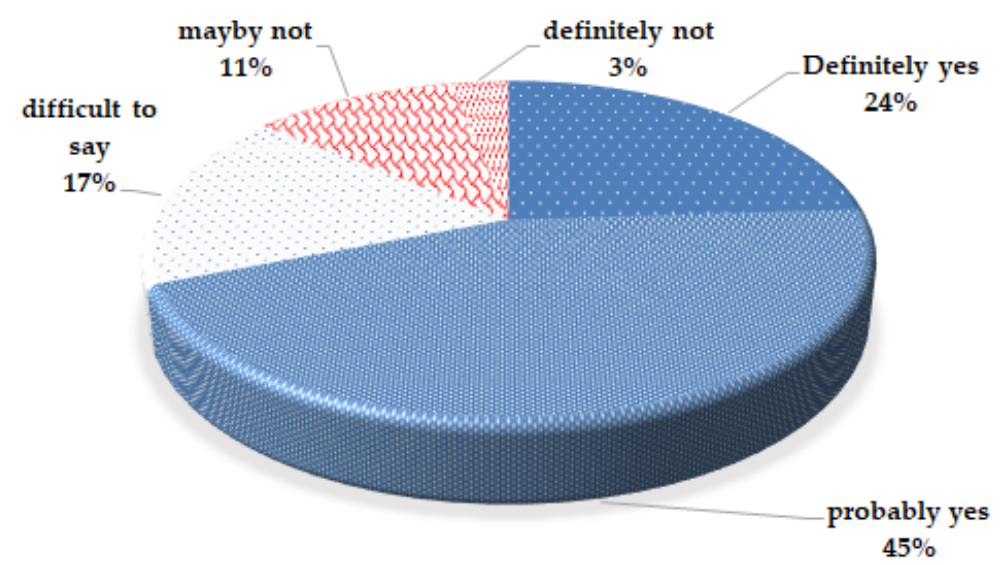

Figure 9. The importance of corporate social responsibility in the decision to purchase a personalized product. Source: own study.

The vast majority of respondents (probably yes- $46 \%$ and definitely yes-21\%) use personalized products longer than standard ones. This is very positive information in terms of sustainable consumption. Only $6 \%$ of respondents definitely denied using personalized products longer than standard ones (Figure 10). 


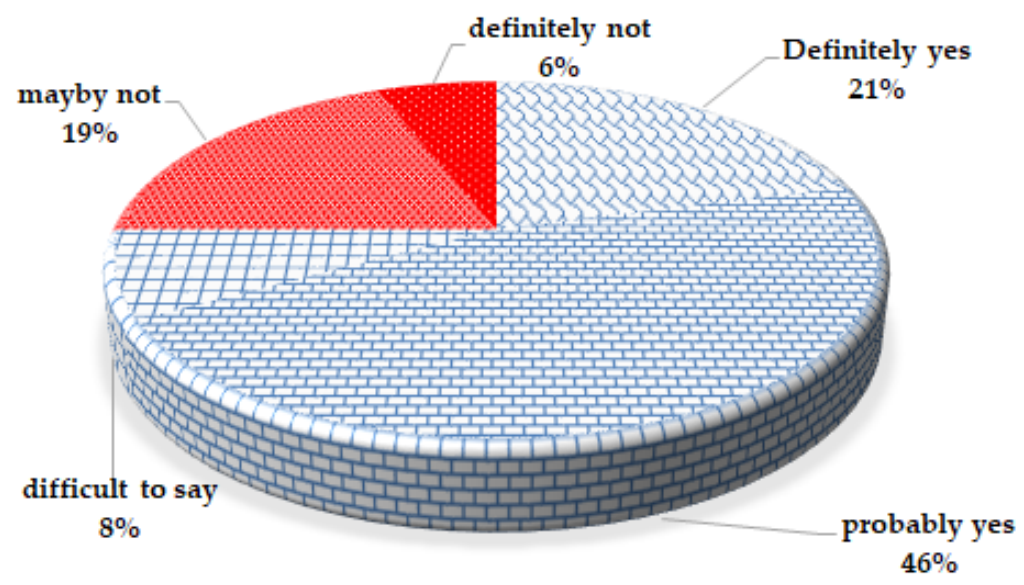

Figure 10. Satisfaction with the long-term use of a personalized product. Source: own study.

\subsection{Stage II-Results of Research}

In the first step of Servqual's analysis, the differences between the level of perception of purchasing of personalized products and the level expected in relation to the five dimensions were calculated, and the results are presented in Table 2.

Table 2. Expected and perceived satisfaction with purchasing a personalized product.

\begin{tabular}{|c|c|c|c|}
\hline Features & $\begin{array}{l}\text { "P" are Individual } \\
\text { Expectations towards } \\
\text { the Purchase of a } \\
\text { Personalized Product }\end{array}$ & $\begin{array}{l}\text { "E" is the Individual's } \\
\text { Expectations of a Given } \\
\text { Service Delivery }\end{array}$ & $\begin{array}{l}\text { Servqual Results } \\
\text { "SS" is the Level of } \\
\text { Satisfaction } \\
\text { SS = E - P }\end{array}$ \\
\hline \multicolumn{4}{|c|}{ Reliability: the ability to perform the promised service dependably and accurately, reliability of a personalized produc } \\
\hline \multicolumn{4}{|c|}{ Average Servqual for Reliability: -0.57} \\
\hline 1. Reliable presentation of the offer & 6 & 6.05 & 0.05 \\
\hline $\begin{array}{l}\text { 2. Access to all information relevant } \\
\text { to the customer }\end{array}$ & 7 & 5.98 & -1.02 \\
\hline $\begin{array}{l}\text { 3. Usefulness of the } \\
\text { website/application with which the } \\
\text { customer purchases a } \\
\text { personalized product }\end{array}$ & 6 & 4.25 & -1.75 \\
\hline $\begin{array}{l}\text { 4. Reliability of a } \\
\text { personalized product }\end{array}$ & 7 & 7.45 & 0.45 \\
\hline \multicolumn{4}{|c|}{ Assurance: the knowledge and courtesy of employees and their ability to convey trust and confidence } \\
\hline \multicolumn{4}{|c|}{ Average Servqual for Assurance: 0.4} \\
\hline 5. Level of customer service & 5 & 4.98 & -0.02 \\
\hline 6. Real-time customer service & 4 & 4.56 & 0.56 \\
\hline $\begin{array}{l}\text { 7. Customer support in the process of } \\
\text { design/creation of a } \\
\text { personalized product }\end{array}$ & 5 & 5.66 & 0.66 \\
\hline \multicolumn{4}{|c|}{$\begin{array}{l}\text { Tangibles: the appearance of physical facilities, equipment, personnel and communication materials, features of a } \\
\text { personalized product }\end{array}$} \\
\hline \multicolumn{4}{|c|}{ Average Servqual for Tangibles: 0.6} \\
\hline 8. Page/application design & 3 & 4.56 & 1.56 \\
\hline 9. Ease of use of the page/application & 5 & 6.23 & 1.23 \\
\hline 10. Website/application reliability & 6 & 5.56 & -0.44 \\
\hline $\begin{array}{l}\text { 11. Quality of the } \\
\text { personalized product }\end{array}$ & 7 & 7.89 & 0.89 \\
\hline
\end{tabular}


Table 2. Cont.

\begin{tabular}{|c|c|c|c|}
\hline Features & $\begin{array}{l}\text { "P" are Individual } \\
\text { Expectations towards } \\
\text { the Purchase of a } \\
\text { Personalized Product }\end{array}$ & $\begin{array}{l}\text { " } \mathrm{E} \text { " is the Individual's } \\
\text { Expectations of a Given } \\
\text { Service Delivery }\end{array}$ & $\begin{array}{l}\text { Servqual Results } \\
\text { "SS" is the Level of } \\
\text { Satisfaction } \\
\text { SS = E - P }\end{array}$ \\
\hline $\begin{array}{l}\text { 12. Compliance with the design of the } \\
\text { personalized product }\end{array}$ & 7 & 6.78 & -0.22 \\
\hline \multicolumn{4}{|c|}{ Empathy: the provision of caring, individualized attention to customers } \\
\hline \multicolumn{4}{|c|}{ Average Servqual for Empathy: -1.92} \\
\hline $\begin{array}{l}\text { 13. Participating in the product } \\
\text { design process }\end{array}$ & 4 & 1.34 & -2.66 \\
\hline $\begin{array}{l}\text { 14. Participation by the customer as } \\
\text { an observer in the production process }\end{array}$ & 3 & 0.23 & -2.77 \\
\hline $\begin{array}{l}\text { 15. Choice of the method of } \\
\text { product delivery }\end{array}$ & 6 & 5.67 & -0.33 \\
\hline \multicolumn{4}{|c|}{ Responsiveness: the willingness to help customers and to provide prompt service } \\
\hline \multicolumn{4}{|c|}{ Average Servqual for Responsiveness: 0.41} \\
\hline 16. Customer data security & 5 & 5.67 & 0.67 \\
\hline $\begin{array}{l}\text { 17. Security of the customized } \\
\text { product design }\end{array}$ & 5 & 5.23 & 0.23 \\
\hline 18. Order completion time & 6 & 6.34 & 0.34 \\
\hline
\end{tabular}

Based on the results of Table 2, an chart has been drawn up, which contains the results of the Servqual perception and expectations method. Figure 11 characterizes the graphical form of the results obtained in the Servqual method.

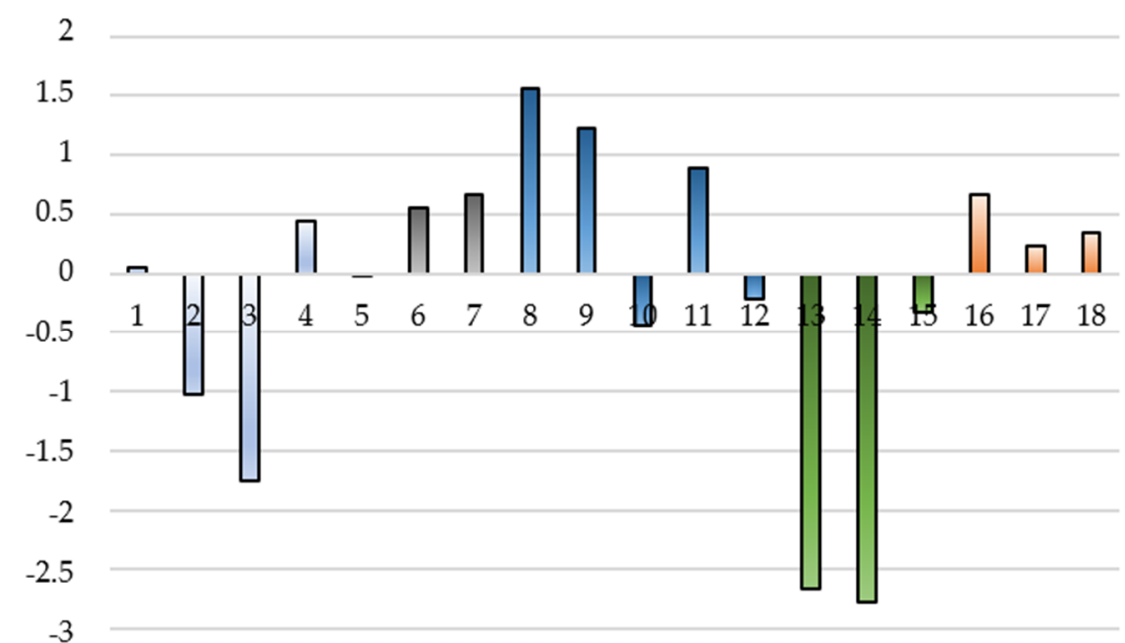

Figure 11. Results of Servqual perception analysis-expectations. Source: own study.

The analysis shows that in 10 out of 18 possible cases, consumer satisfaction was achieved, while in the remaining eight cases, unfortunately, there is no satisfaction level with the purchase of a personalized product. However, as you can see, the areas of dissatisfaction relate to the purchase process itself, not to specific product characteristics. Thus, it can be assumed that they will not have a major impact on sustainable consumption, e.g., reducing the lifetime of a personalized product.

The results of the research made it possible to identify the factors that affect the reduction in customer satisfaction that should be improved. These are the access to all information relevant to the customer, usefulness of the website/application with which the customer purchases a personalized 
product, level of customer service, reliability of the website/application, compliance with the design of the personalized product, participation in the product design process, participation of the customer as an observer in the production process, and the choice of the method of product delivery.

The most satisfactory factors include: reliable presentation of the offer, reliability of the personalized product, real-time customer service, customer support in the process of design/creation of the personalized product, page/application design, ease of use of the page/application, customer data security, the security of the personalized product design, and lead time. Figure 12 shows the results of the arithmetic mean calculation for each of the tested areas of the Servqual method.

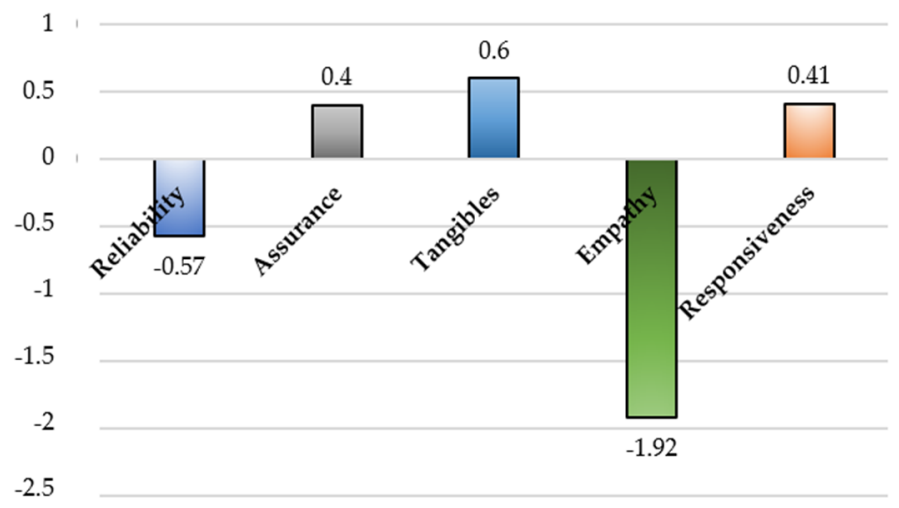

Figure 12. Arithmetic mean score for Servqual analysis dimensions. Source: own study.

Positive arithmetic means were obtained for the dimensions: assurance, tangibles, and responsiveness, which means that the satisfaction of the respondents was achieved for these dimensions. The dimensions where the satisfaction of the respondents has not been achieved and needs to be improved are: reliability and empathy.

The next step in the Servqual method was to calculate the total arithmetic measure of consumer satisfaction (which is -0.38). The result was negative, but slightly different from zero, which indicates the need to improve the level of service quality when ordering and manufacturing personalized products.

The last step was to assess the importance of the five dimensions. The consumers surveyed distributed 100 points between the listed satisfaction and quality criteria. Table 3 shows the assessment of importance of the dimensions according to the respondents.

Table 3. Validation assessment of five dimensions for the Servqual analysis.

\begin{tabular}{ccc}
\hline Feature Category & \multicolumn{2}{c}{ Evaluation } \\
\hline Reliability & 22.85 & 0.23 \\
\hline Assurance & 26.78 & 0.27 \\
\hline Tangibles & 25.00 & 0.25 \\
\hline Empathy & 15.24 & 0.15 \\
\hline Responsiveness & 10.13 & 0.1 \\
\hline Total score & $\sum=100$ & $\sum=1$ \\
\hline
\end{tabular}

Source: own study.

The mean values were used to calculate the weighted average of the individual dimensions as well as the total weighted average of the Servqual method and are then presented in Table 4. 
Table 4. Weighted averages for the Servqual analysis.

\begin{tabular}{cccc}
\hline Feature Category & Indicator Weight $\sum=\mathbf{1}$ & $\begin{array}{c}\text { Servqual Average for } \\
\text { Each Feature Category }\end{array}$ & Weighted Average \\
\hline Reliability & 0.23 & -0.57 & $-0.57 * 0.23=-0.13$ \\
\hline Assurance & 0.27 & 0.4 & $0.4 * 0.27=0.10$ \\
\hline Tangibles & 0.25 & 0.6 & $0.6 * 0.25=0.15$ \\
\hline Empathy & 0.15 & -1.92 & $-1.92 * 0.15=-0.29$ \\
\hline Responsiveness & 0.1 & 0.41 & $0.41 * 0.1=0.04$ \\
\hline & Weighted average sum of five areas & -0.13 \\
\hline & $\begin{array}{c}\text { Total weighted average Servqual } \\
\text { Sum of weighted averages for the areas under study/5 }\end{array}$ & -0.13 \\
\hline
\end{tabular}

Source: own study.

The results of the analysis of the weighted average of the examined measures of customer satisfaction with the purchase of a personalized product, including the quality of service, showed that three areas are satisfactory for consumers (assurance, tangibles, responsiveness) and two areas require absolute improvement (empathy, reliability), which confirms previous calculations. The results obtained are presented in Figure 13.

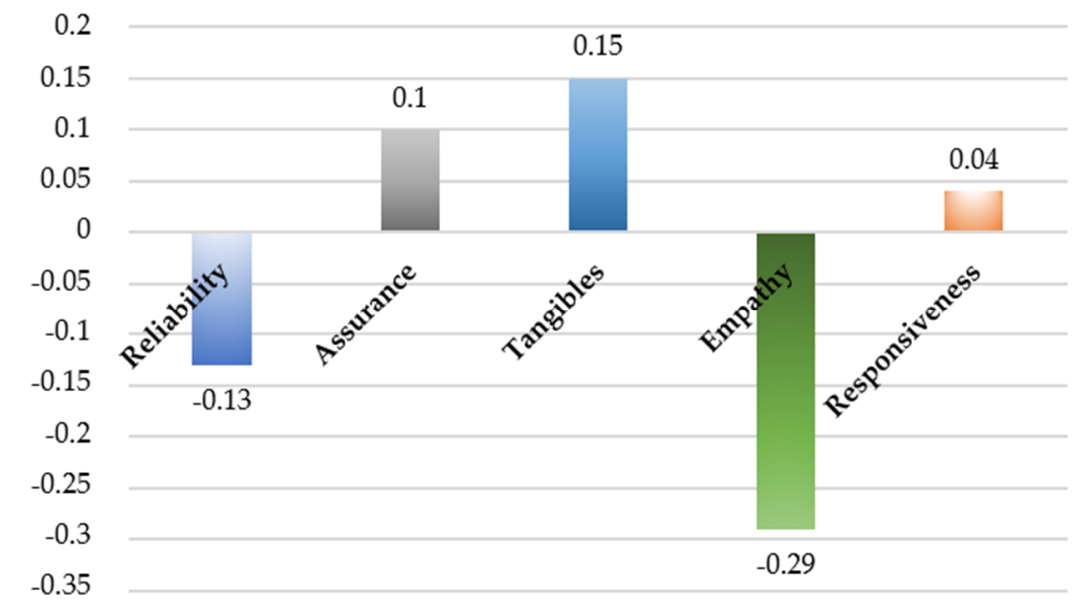

Figure 13. Weighted average result for the Servqual analysis dimensions of the tested measures of customer satisfaction with the purchase of a personalized product including service quality. Source: own study.

The areas that most need to be changed are empathy and reliability, the other areas of the analysis are above zero, so the level of satisfaction with the purchase of personalized products is close to expectations. This is also indicated by the positive result of the total Servqual weighted average.

Table 5 shows the expected impact of the individual characteristics on the overall level of consumption in the long term and the level of sustainable consumption, especially in relation to the consumption of personalized products: $(+)$-increase, $(-)$ - decrease, $(+/-)$-neutral. 
Table 5. Impact of the characteristics on changes in overall and sustainable consumption.

\begin{tabular}{|c|c|c|c|}
\hline & Characteristics & $\begin{array}{l}\text { Level of Overall } \\
\text { Consumption in the } \\
\text { Long Run }\end{array}$ & $\begin{array}{l}\text { Level of Sustainable } \\
\text { Consumption } \\
\text { and Production }\end{array}$ \\
\hline \multicolumn{4}{|c|}{ Reliability } \\
\hline 1. & Reliable presentation of the offer & + & + \\
\hline 2. & $\begin{array}{l}\text { Access to all information relevant to the } \\
\text { customer }\end{array}$ & + & + \\
\hline 3. & $\begin{array}{l}\text { The usability of the site/application with } \\
\text { which the customer purchases a } \\
\text { personalized product }\end{array}$ & - & + \\
\hline 4. & Reliability of a personalized product & - & + \\
\hline \multicolumn{4}{|c|}{ Assurance } \\
\hline 5. & Customer service level & + & $+/-$ \\
\hline 6. & Real-time customer service & $-1+$ & + \\
\hline 7. & $\begin{array}{l}\text { Customer support in the process of } \\
\text { design/creation of a personalized product }\end{array}$ & - & + \\
\hline \multicolumn{4}{|c|}{ Tangibles } \\
\hline 8. & Page/application design & $-/+$ & $+/-$ \\
\hline 9. & Ease of page/application operation & $-/+$ & + \\
\hline 10. & Website/application reliability & $-/+$ & + \\
\hline 11. & Quality of a personalized product & - & + \\
\hline 12. & $\begin{array}{l}\text { Compatibility with a personalized } \\
\text { product design }\end{array}$ & - & + \\
\hline \multicolumn{4}{|c|}{ Empathy } \\
\hline 13. & $\begin{array}{l}\text { Participation in the product } \\
\text { design process }\end{array}$ & - & + \\
\hline 14. & $\begin{array}{l}\text { Participation by the customer as an } \\
\text { observer in the production process }\end{array}$ & - & + \\
\hline 15. & Choice of product delivery method & $+/-$ & + \\
\hline \multicolumn{4}{|c|}{ Responsiveness } \\
\hline 16. & Customer data security & $+/-$ & $+/-$ \\
\hline 17. & Security of the customized product design & - & + \\
\hline 18. & $\begin{array}{l}\text { Shorter lead times for } \\
\text { customized products }\end{array}$ & - & + \\
\hline
\end{tabular}

Source: own study.

The higher level of customization and a greater level of consumer involvement in the design of personalized products will contribute to lower overall long-term consumption and increase sustainable consumption. Due to the increasing availability of modern ICT, IoT, Cloud Computing, and Big Data, modern companies should involve the consumer more in the process of manufacturing new products.

\section{Conclusions}

In the turbulently changing environment enterprises are forced to search for the most effective methods of monitoring and detecting changes in the environment, to take effective adaptation activities leading to a continuous build competitive advantage [38-40]. Sustainable consumption and production $(\mathrm{SCP})$ is one of the many EU priorities [41], tries to combine on the one hand the need to meet needs, 
improve the quality of life, and on the other hand, improve resource efficiency, increase the use of renewable energy sources, and minimize waste. The integration of these elements is the main goal of modern economies, which want to provide the same or better services to meet the basic requirements of life and aspirations to improve the quality of life while constantly reducing environmental damage and risks to human health. Modern companies are forced to meet the high demands of consumers, who more and more often expected tailor-made products and are increasingly aware of the negative effects of excessive consumption.

Analyzing the variety of product offers available on the modern global market, it can be concluded that consumers are getting more and more and expect more and more for various reasons. Thus, the question is whether it is possible to create a product and offer it in such a way that buyer satisfaction reaches and remains very high for a long time. The products offered on the market would not have such a short product life and better meet consumers' expectations.

The research shows a high level of satisfaction with the purchase of personalized products and great interest in increasing consumer involvement in the process of adapting products. This increase in satisfaction translates into a level of satisfaction with the long-term use of personalized products and a general reduction in consumption. Noteworthy is the increase in awareness of the modern consumer and the attention paid to the social responsibility of producers. Social media creates new behaviors based on conscious consumption, the development of sharing economy behaviors and care for the natural environment. There is no doubt that such a profile of a modern consumer has been greatly influenced by the development of the Internet, mobile telephony, market globalization and many other determinants having their roots in the macro-environment. Furthermore, the results of research mean that there is a great need to personalize production, especially for more complex products. The answers of respondents confirm the high level of satisfaction with having a personalized product and no reason to replace it with another one, which can significantly reduce consumption and attachment to the once purchased product for a longer period. The time of waiting for a personalized product and participation in the selection of options or product design proves high consumer maturity. A mature consumer wants to purchase products tailored to their needs and use them for a long time if they meet expectations. This is a prerequisite for achieving a higher level of sustainable consumption.

It turns out that in the era of the Fourth Industrial Revolution, the strategy of mass personalization makes it possible to become closer to this goal. Nowadays, enterprises will have to change their orientation from product to services in the networks. Offering a high level of design, manufacturing and logistics services, and offering personalized products manufactured in sophisticated networks of enterprises using technologies of Industry 4.0, means active interaction with consumers, and the level of product creation is transferred from the perspective of creating only a physical product to creating new experiences and building consumer satisfaction. When buying a personalized product, the customer makes this purchase with greater awareness and feels more satisfaction with the purchase, which leads to a reduction in the overall level of consumption in the long term and an increase in sustainable consumption.

Nowadays, enterprises should therefore go beyond the standard exploration of market potential by meeting the needs of consumers and offer a high level of service oriented towards involving the consumer in the process of designing, manufacturing and delivering the product to the customer to meet their individual preferences.

The research conducted leads to further research in the future to demonstrate the impact of personalized production on extending the product life cycle and reducing overall consumption by analyzing the behavior of modern consumers. Furthermore, developing tools to improve the consumer-producer relationship aimed at greater consumer involvement in the process of designing and manufacturing personalized products. Particularly interesting is the increase in the contemporary consumer's awareness of the lack of the need for the impulsive purchasing of lifeless products. An important impulse to change consumer behavior is also the situation of the coronavirus pandemic 
(COVID-19) and lifestyle remodeling and the increase in the importance of health and environmental protection for future generations.

Author Contributions: The main activities of the team of authors can be described as follows: conceptualization, S.G., S.S.; methodology, S.G., S.S.; software, S.S.; validation, S.G., S.S.; formal analysis, S.G., S.S.; investigation, S.G., S.S., resources, S.G., S.S., B.G.; data curation, S.G., S.S.; writing-original draft preparation, S.G., S.S., B.G., writing - review and editing, S.G., S.S., B.G.; visualization, S.G., S.S.; supervision, S.G., S.S., and B.G.; funding acquisition, S.S. All authors have read and agreed to the published version of the manuscript.

Funding: This research received no external funding.

Conflicts of Interest: The authors declare no conflict of interest.

\section{References}

1. Di Giulio, A. Conceptualizing sustainable consumption: Toward an integrative framework. Sustainability 2014, 10, 45-61. [CrossRef]

2. Kumar, V.; Zillur, R.; Kazmi, A. Sustainability marketing strategy: An analysis of recent literature. Glob. Bus. Rev. 2014, 14, 601-625. [CrossRef]

3. Promoting Sustainable Consumption Requires the Involvement of Both Professionals and Public Authorities and Individuals. Available online: http://ec.europa.eu/environment/eussd/pdf/report_22082012. pdf (accessed on 12 September 2020).

4. Cloke, P.; Clarke, N.; Malpass, A. Globalizing Responsibility: The Political Rationalities of Ethical Consumption; Wiley-Blackwell: Oxford, UK, 2011.

5. Consumption, Promoting Sustainable. Good Practices in OECD Countries. 2008. Available online: https: //www.oecd.org/greengrowth/40317373.pdf (accessed on 12 September 2020).

6. Transforming Our World: The 2030 Agenda for Sustainable Development A/RES/70/1. Available online: https://sustainabledevelopment.un.org/topics/sustainableconsumptionandproduction (accessed on 12 September 2020).

7. Silveira, G.D.; Borenstein, D.; Fogliatto, F.S. Mass customization: Literature review and research directions. Int. J. Prduction Econ. 2001. [CrossRef]

8. Lampel, J.; Mintzberg, H. Customizing Customization. Sloan Manag. Rev. 1996, 38, 21-30.

9. Korena, Y.; Shpitalnib, M.; Guc, P.; Hu, S.J. Product design for mass-individualization. Procedia CIRP 2015, 36, 64-71. [CrossRef]

10. Venasen, J. What is personalization. A conceptual framework. Eur. J. Mark. 2007, 41, 409-418.

11. Zhou, F.; Ji, Y.; Jiao, R. Affective and cognitive design for mass personalization: Status and prospect. J. Intell. Manuf. 2013, 24, 1047-1069. [CrossRef]

12. Arora, N.; Dreze, X.; Ghose, A.; Hess, J.; Iyengar, R.; Jing, B.; Joshi, Y.; Kumar, V.; Lurie, N.; Neslin, S.; et al. Putting one-to-one marketing to work: Personalization, customization, and choice. Mark. Lett. 2008, 19, 305-321. [CrossRef]

13. Kumar, A. From mass customization to mass personalization: A strategic transformation. Int. J. Flex. Manuf. Syst. 2007, 19, 533-547. [CrossRef]

14. Tseng, M.M.; Jiao, R.J.; Wang, C. Design for mass personalization. CIRP Ann. Manuf. Technol. 2010, 59, 175-178. [CrossRef]

15. Peppers, D.; Rogers, M. The One-to-One Future; Double Day Publications: New York, NY, USA, 1997.

16. Riemer, K.; Totz, C. The many faces of personalization? An integrative economic overview of mass customization and personalization. In Proceedings of the World Conference on Mass Customization, Personalization, and Co-Creation, Hong Kong, China, 2010.

17. Chellappa, R.K.; Sin, R. Personalization versus privacy: An empirical examination of the online consumer's dilemma. Inf. Technol. Manag. 2005, 6, 181-202. [CrossRef]

18. Birkel, H.S.; Veile, J.W.; Müller, J.M.; Hartmann, E.; Voigt, K.I. Development of a risk framework for Industry 4.0 in the context of sustainability for established manufacturers. Sustainability 2019, 11, 384. [CrossRef]

19. Niehoff, S.; Beier, G. Industrie 4.0 and a sustainable development: A short study on the perception and expectations of experts in Germany. Int. J. Innov. Sustain. Dev. 2018, 12, 360. [CrossRef]

20. Blom, J.; Monk, A. Theory of personalisation of appearance: Why people personalise their mobile phones and PCs. Human Comput. Interact. 2003, 18, 193-228. [CrossRef] 
21. Hu, S.J. Evolving paradigms of manufacturing: From mass production to mass customization and personalization. Procedia CIRP 2013, 7, 3-8. [CrossRef]

22. Senanayake, M.M.; Little, T.J. Mass customization: Points and extent of apparel customization. J. Fash. Mark. Manag. 2010, 14, 282-299. [CrossRef]

23. Stock, T.; Seliger, G. Opportunities of Sustainable Manufacturing in Industry 4.0. Procedia CIRP 2016, 40, 536-541. [CrossRef]

24. Szozda, N. Industry 4.0 and its impact on the functioning of supply chains. LogForum 2017, 13, 401-414. [CrossRef]

25. Gold, S.; Seuring, S.; Beske, P. Sustainable Supply Chain Management and Inter-Organizational Resources: A Literature Review. Corp. Soc. Responsib. Environ. Manag. 2010. [CrossRef]

26. Montgomery, A.M.; Smith, M.D. Prospects for personalization on the internet. J. Interact. Mark. 2009, 23, 130-137. [CrossRef]

27. Berman, B. 3-D printing: The new industrial revolution. Bus. Horiz. 2012, 55, 155-162. [CrossRef]

28. Fratocchi, L. Is 3D Printing an Enabling Technology for Manufacturing Reshoring? In Reshoring of Manufacturing: Drivers, Opportunities, and Challenges; Vecchi, A., Ed.; Springer International Publishing: Basel, Switzerland, 2017; pp. 99-124.

29. Barnett, C.; Clarke, N.; Cloke, P.; Malpass, A. The political ethics of consumerism. Consum. Policy Rev. 2005, 15, 45-51.

30. Wang, Y.; Ma, H.-S.; Yang, J.-H.; Wang, K.-S. Industry 4.0: A way from mass customization to mass personalization production. Adv. Manuf. 2017, 5, 311-320. [CrossRef]

31. Kiel, D.; Müller, J.M.; Arnold, C.; Voigt, K.I. Sustainable industrial value creation: Benefits and challenges of industry 4.0. Int. J. Innov. Manag. 2017, 21, 1740015. [CrossRef]

32. Lofthouse, V.A.; Prendeville, S. Considering the User in the Circular Economy. In Proceedings of the PLATE Conference, Delft University of Technology, Delft, The Netherlands, 8-10 November 2017.

33. Helu, M.; Hedberg, T., Jr. Enabling smart manufacturing research and development using a product lifecycle test bed. Procedia Manuf. 2015, 1, 86-97. [CrossRef]

34. Beier, G.; Ullrich, A.; Niehoff, S.; Reißig, M.; Habich, M. Industry 4.0: How it is defined from a sociotechnical perspective and how much sustainability it includes-A literature review. J. Clean. Prod. 2020, 259, 120856. [CrossRef]

35. Higgs, B.; Polonsky, M.J.; Hollick, M. Measuring Expectations: Pre and Post Consumption: Does It Matter? J. Retail. Consum. Serv. 2005, 12, 49-64. [CrossRef]

36. Yang, Z.; Jun, M. Consumer Perception of E-Service Quality: From Internet Purchaser and Non-purchaser Perspectives. J. Bus. Strateg. 2008, 25, 59-84.

37. Ciechomski, W. Masowa kastomizacja jako forma komunikacji rynkowej z konsumentami. Prace Nauk. Uniw. Ekon. (AE) We Wrocławiu 2015, 414, 77-90.

38. Grabowska, S. Business model metallurgical company built on the competitive advantage. METAL 2016. In Proceedings of the 25th International Conference on Metallurgy and Materials, Brno, Czech Republic, 25-27 May 2016; pp. 1800-1807.

39. Gajdzik, B.; Grabowska, S.; Saniuk, S.; Wieczorek, T. Sustainable Development and Industry 4.0: A Bibliometric Analysis Identifying Key Scientific Problems of the Sustainable Industry 4.0. Energies 2020, 13, 4254. [CrossRef]

40. Saniuk, S.; Grabowska, S.; Gajdzik, B. Social expectations and market changes in the context of developing the industry 4.0 concept. Sustainability 2020, 12, 1362. [CrossRef]

41. Bluszcz, A.; Manowska, A. Differentiation of the Level of Sustainable Development of Energy Markets in the European Union Countries. Energies 2020, 13, 4882. [CrossRef]

Publisher's Note: MDPI stays neutral with regard to jurisdictional claims in published maps and institutional affiliations. 